\title{
Autorrepresentación en la obra de Torrente Ballester
}

\author{
Susana Arroyo Redondo \\ Universidad de Alcalá
}

\section{RESUMEN}

Con ocasión del centenario del nacimiento de Gonzalo Torrente Ballester (1910-1999), este artículo propone una exploración de su permanente búsqueda de nuevas formas de autorrepresentación literaria. A lo largo de su carrera, la preocupación de Torrente por dibujar la vida a través de la ficción le fue llevando lejos de los caminos del realismo, hacia nuevas concepciones sobre la representación literaria basadas en la autenticidad y la subjetividad (como puede verse en Don Juan y Dafne y ensueños). Su creciente irracionalismo resultó en un esfuerzo por reflexionar sobre los límites de la verosimilitud y el poder persuasivo de las palabras. Estos experimentos con la verdad y la ficción son analizados según aparecen en varios textos de Torrente, especialmente Yo no soy yo, evidentemente, un paródico homenaje a Fernando Pessoa.

Palabras clave: Torrente Ballester, autorretrato, relato personal, experimentación.

\section{Self-representative in Torrente Ballester's works}

\begin{abstract}
On the occasion of the centenary of the birth of Gonzalo Torrente Ballester (1910-1999), this article explores his permanent search for new forms of literary self-representation. Throughout his career, the concern to capture life through fiction led Torrente away from the traditional paths of realism, to radical new conceptions of literary representation based on authenticity and subjectivity (as developed in Don Juan and Dafne y ensueños). His increasing irrationalism resulted in an effort to re-think the limits of verisimilitude and the persuasive power of words. These experiments with truth and fiction are analysed as they appear in several of Torrente writings, especially Yo no soy yo, evidentemente, a parodical homage to Fernando Pessoa.
\end{abstract}

Key words: Torrente Ballester, self-portrait, personal story, experimentation.

\section{CONTEXTUALIZACIÓN}

La celebración del centenario del nacimiento de Gonzalo Torrente Ballester (Serantes, Ferrol, 1910 - Salamanca, 1999) ofrece una oportunidad inmejora- 
ble para el recuerdo y revisión de la trayectoria literaria de uno de los más polifacéticos escritores del siglo XX español. Hombre de contradicciones y prosista genial, sus dos obras más celebradas se sitúan en posiciones estéticas completamente opuestas: por un lado, la conocida novela realista Los gozos y las sombras, y por otro, La saga/fuga de J.B., epítome del experimentalismo de vanguardia sobre la que el premio Nobel José Saramago afirmaría: «hasta ahora había una silla vacía a la derecha de Cervantes, que acaba de ser ocupada por Gonzalo Torrente Ballester ${ }^{1}$. Sin embargo, más allá de estos textos, buena parte de la prolífica obra del escritor gallego resulta aún poco conocida. El alcance de su complejo y contradictorio mundo creativo, a caballo entre el racionalismo clasicista y el imaginario surrealista, merece una profunda reconsideración a la luz de un nuevo siglo. Este artículo pretende contribuir modestamente a dicho esfuerzo de reivindicación ${ }^{2}$.

En concreto, se prestará especial atención a la producción de Torrente Ballester durante la década de los setenta y ochenta, pues resulta muy relevante a la hora de trazar una semblanza sobre su identidad literaria. Al compás de los movimientos socioculturales nacionales e internacionales de la época, el gallego desarrolló una fuerte noción irrealista de la literatura que huía de la réplica del mundo para ahondar en la autonomía del lenguaje. En consonancia con la cultura posmoderna del simulacro y la equivalencia semántica entre la realidad y su representación, las novelas metaficticias de Torrente Ballester durante estas décadas se muestran abiertas a la experimentación, y sin embargo, mantienen su enfoque clásico sobre el mito y la reflexión intelectual. Para ejemplificar los postulados de este análisis, la obra de referencia será Yo no soy yo, evidentemente, una novela que no sólo ocupa un puesto destacado en la cronología de las publicaciones torrentinas, sino que retoma con amplitud los temas del irrealismo que aquí se analizarán. Por más que esta novela no pueda considerarse autobiográfica, expone de forma insuperable las estrategias de representación de la identidad personal exploradas por el gallego durante toda su carrera.

En resumen, las páginas que siguen proponen abordar la dependencia entre fantasía metaliteria y recreación personal de la producción literaria de Torrente Ballester, poniendo dichas obras en relación con el ambiente cultural en que fueron gestadas y recibidas. Para ello, se desarrollarán los tres siguientes puntos: primero, una valoración sobre el desarrollo literario de To-

\footnotetext{
${ }^{1}$ Saramago, José (1997). «Perfiles cervantinos en la obra de Torrente», en Carmen Becerra; Ángel Candelas y Ángel Abuín González (eds.), La creación literaria de Gonzalo Torrente Ballester. Vigo: Tambre, pp. 13-22, 21.

${ }^{2}$ Para un análisis preciso de la producción más célebre del autor, véase Ángel G. Loureiro (1990). Mentira y seducción: la trilogía fantástica de Torrente Ballester. Madrid: Castalia, pp. 13-44; y Antonio J. Gil González (2003). Relatos de poética: para una poética del relato de Gonzalo Torrente Ballester. Santiago de Compostela: Universidad de Santiago de Compostela, pp. 39-110.
} 
rrente Ballester; segundo, la influencia de los heterónimos del poeta Fernando Pessoa sobre la configuración de una noción irrealista de la identidad literaria; y por último, una reflexión sobre las conexiones intelectuales del gallego con el desarrollo filosófico del yo en la cultura contemporánea.

\section{DeSARRollo Literario}

Para comenzar, resulta un tópico imprescindible señalar hasta qué punto la prolífica prosa de Torrente Ballester desplegó a lo largo de su zigzagueante carrera unas complicadas relaciones con el realismo y la fantasía. No se trata de que ambos elementos conformasen polos temáticos o estilísticos separados, sino de que Torrente asumió como propias dos tradiciones literarias divergentes.

Conviene recordar, como episodios anteriores y capitales, mi descubrimiento de lo que se llamaba entonces el superrealismo (1927-28) que me permitió averiguar que yo lo era, y, cuatro años más tarde, del clasicismo consciente en sus formas más modernas y paradójicas (Poe, Baudelaire, Mallarmé), merced a lo cual llevé a buen puerto un segundo descubrimiento: que el arte como conciencia también me solicitaba, y que algo afín llevaba en mi interior. De la colisión entre el uno y el otro, no sólo salió cuanto llevo escrito, sino yo mismo: pues no fueron dos adquisiciones de las que pudiera librarme a voluntad, sino, insisto, dos descubrimientos sucesivos y contradictorios de maneras de ser reales y personales. Hubiera podido inventarme un heterónimo clásico y otro romántico, y echarlos a pelear. No lo hice porque no se me ocurrió. Afortunadamente ${ }^{3}$.

Aunque el irracionalismo y la estética clásica conviven en todas las obras de Torrente Ballester de modos más o menos armoniosos, su uso de ambos motivos fue variando a lo largo del tiempo conforme el desarrollo de las modas literarias. Vista desde un enfoque cronológico, la dilatada trayectoria profesional de Torrente Ballester, aunque sin duda muy personal, da buena cuenta de los vaivenes culturales de toda la segunda mitad del siglo XX europeo: la impersonalidad narrativa de la década de los cuarenta, el impulso experimental de los setenta y la investigación de líneas menos comprometidas tanto estética como socialmente típica de las postrimerías del siglo ${ }^{4}$. En consonancia con el impulso de exploración personal que domina la narrativa posmoderna, la prosa de Torrente Ballester también registró una evolución desde formas de expresión impersonales (omnisciencia y tercera persona) hacia otras más íntimas y autoconscientes (enfoque y expresión desde la primera perso-

\footnotetext{
${ }^{3}$ Torrente Ballester, Gonzalo (2006). «Curriculum, en cierto modo», La Tabla Redonda, 4, pp. 121-136, 131.

${ }^{4}$ Pozuelo Yvancos, José María (2004). Ventanas de la ficción. Barcelona: Península, p. 45.
} 
na). Así, por más que todas las obras del gallego siempre combinen elementos contradictorios, existen matices que posibilitan la visualización de diversas fases creativas en su larga trayectoria como escritor. En este sentido, la triple división cronológica establecida con carácter didáctico por Antonio J. Gil González ${ }^{5}$ resulta muy útil para mejor adentrarse en las relaciones bidireccionales de la prosa de Torrente Ballester a lo largo del tiempo. A través de ella resultará sencillo observar cómo las cuestiones sobre la multiplicidad del yo que aquí se abordan, aunque siempre presentes en la prosa del gallego, se desarrollaron junto a su vertiente fantástica hasta el punto de crear un universo literario de paródica búsqueda existencial.

En su primera etapa de consolidación como escritor, desde la década de los cuarenta con Javier Mariño (1943) hasta finales de los sesenta con Offside (1969), el empuje del realismo social imperante en la España franquista de la posguerra española ejerció un innegable influjo en su prosa. Tal y como reflejan otras obras de la misma etapa —El golpe de estado de Guadalupe Limón (1946), Ifigenia (1950) y la trilogía de Los gozos y las sombras (19571962) - la prosa de Torrente Ballester, aunque lejos del objetivismo típico asociado al realismo, sí está dominada por la impersonalidad y la voz en tercera persona. En este sentido, aunque algunas de sus narraciones se encaucen desde la primera persona gramatical y un punto de vista homodiegético, al final estarán enmarcadas en una estructura o diégesis superior enunciada en tercera persona. La única excepción en este período la constituye Don Juan (1963) - una obra denostada por la crítica y un fracaso de público en su momento, aunque entre todas sus creaciones tal vez sea la más apreciada por el propio Torrente Ballester-, que anuncia ya temas fundamentales de su segunda etapa de creación. El nuevo ciclo, que Gil González califica como «ficciones del yo» ${ }^{6}$, se abrirá con La saga/fuga de J.B. (1972), su famosa novela experimental y primera parte de su «trilogía fantástica» junto con Fragmentos de Apocalipsis y La isla de los jacintos cortados, y alcanzará hasta Yo no soy yo, evidentemente (1987), obra sujeta a una fuerte influencia de Pessoa y centrada en la cuestión de los heterónimos. Dicho periodo, que biográficamente corresponde a la ruptura de Torrente Ballester con la problemática española y su exilio a los Estados Unidos como profesor universitario en Albany, se caracteriza por el uso extensivo de la voz en primera persona, elementos fantásticos, intertextualidad, reflexión metaliteraria, paradojas sobre la identidad y una apuesta arriesgada por la innovación formal ${ }^{7}$. El irrealismo que dominó su obra

${ }^{5}$ Gil González, Antonio J (2008). «Identidad y mutación en la 'novelística del yo' de Gonzalo Torrente Ballester: Quizá nos lleve el viento al infinito y otras narraciones indecisas», en Carmen Becerra y Emilie Guyard (eds.), Los juegos de la identidad movediza en la obra de Gonzalo Torrente Ballester. Vigo: Academia del Hispanismo, pp. 83-103, 86.

${ }^{6}$ Ibidem.

${ }^{7}$ Una excepción al tono metaliterario y jugueteo autobiográfico de esta época parecería constituirlo La princesa durmiente va a la escuela, obra que se caracteriza por un aire de 
durante estas décadas, aunque pueden rastrearse en toda su carrera, se manifiestan con gran intensidad sobre todo en Yo no soy yo, evidentemente: novela de excepcional alcance reflexivo a partir de la cual Torrente Ballester abandonaría su compromiso cerrado con lo fantástico y la reflexión metaliteraria para introducirse en nuevos caminos. De hecho, en una larga tercera etapa inaugurada por Filomeno a mi pesar (1988), con un Torrente Ballester octogenario, reconocido por diferentes premios y ya bien asentado en el panorama editorial español, las dos modalidades de realismo y surrealismo se combinan y suceden en su prosa, aunque en ningún momento se vuelve al tono autorial y de intriga metaliteraria característico de la segunda etapa, sólo recuperado tal vez en su última obra, Los años indecisos (1998).

Será su segunda etapa la que más importe estudiar aquí, pues es donde con más intensidad se manifiesta la asociación entre irrealismo y recreación imaginaria de la identidad personal. De forma significativa, en dicha etapa se incrementaría además el diálogo continuo entre realidad y fantasía que le valiera al gallego la fama de ser la respuesta española al realismo mágico hispanoamericano. Una etiqueta que, como revela García de la Concha, Torrente Ballester rechazaba rotundamente porque cuando se habla convencionalmente de realismo «se disminuye el alcance de lo real», y él «quería ir más allá», ya que creía que «todo lo que podemos nombrar es real» y «el único límite que debe imponerse el novelista es el de la verosimilitud» ${ }^{8}$. Desde esta perspectiva, se podrá adquirir una visión más precisa sobre la relación entre fantasía y recreación personal en los libros que Torrente Ballester dio a la imprenta durante este segundo periodo creativo. Todos, como ya se ha mencionado, establecen una investigación sobre los márgenes de la realidad y de la personalidad, y además, varios se centran de forma abierta y explícita en los problemas para la configuración estable de una noción del yo. Entre ellos, aquí nos interesarán los que ya habíamos mencionado: Don Juan (1963, que incluimos aquí por ser una excepción al tono de la primera etapa y avanzar todos los grandes temas de la segunda) ${ }^{9}$, Fragmentos de Apocalipsis (1977),

fantasía clásica más propio de la primera etapa de Torrente; sin embargo debe tenerse en cuenta que dicha obra, por más que no encontrara editor hasta 1983, fue en realidad escrita y ultimada hacia 1950.

${ }^{8}$ Mendoza, Ana (2007). «Homenaje a Gonzalo Torrente Ballester por la reedición de Los gozos y las sombras». [En línea]. elmundo.es. 14 noviembre 2007, http://www.elmundo.es/ elmundo/2007/11/14/cultura/1195042569.html [consulta: 10 septiembre 2009].

${ }^{9}$ Sobre la peculiar naturaleza y proceso de gestación de Don Juan con respecto a otros textos del mismo periodo, véase la siguiente declaración: «Sucedió que Los gozos y las sombras me dejaron fatigado de realismo, y presté atención, hasta llegar a escribirlo, a otro asunto que me traía preocupado desde algunos años atrás, el de Don Juan. Me hallé en él a mis anchas, y más en mi terreno; comprendí que al no excluir la fantasía, las posibilidades del despliegue imaginativo eran mayores», en Gonzalo Torrente Ballester (1986). «Nota autobiográfica», Anthropos, 1986, 66-67, pp. 19-21, 20. 
Dafne y ensueños (1982), Quizá nos lleve el viento al infinito (1984) y ante todo Yo no soy yo, evidentemente (1987). Estos libros tienen en común presentar personajes que, además de aludir a diferentes facetas del propio Torrente, viven en un perpetuo conflicto personal y parecen incapaces de definir su identidad de forma estable. Dichos personajes muestran la misma inestabilidad mediante tres técnicas diferentes.

En primer lugar, un yo de sutil existencia que sólo se manifiesta por la asimilación y suplantación serial de otros. Estamos hablando en concreto del diablo Leporello en Don Juan y del extraño espía conocido como el «Maestro de las pistas que se pierden en la niebla», que protagoniza la novela de ficción utópica Quizá nos lleve el viento al infinito. Ambos seres, el primero por su naturaleza diabólica, el segundo tal vez por ser un robot, tienen la capacidad mimética de ocupar cuerpos ajenos, adoptando su aspecto, y compartir con sus inquilinos sus vivencias y recuerdos; en otras palabras, ambos personajes manifiestan sus propias personalidades a través de muchos cuerpos o personalidades cambiantes. Pero este motivo fue acrecentando su importancia para Torrente Ballester con el tiempo, y si en el caso de Leporello el mensaje último acaba siendo que tras las múltiples máscaras reside un yo único, en el del Maestro desaparece toda seguridad de que tras los numerosos personajes que ha ido adoptando quede una conciencia independiente.

En segundo lugar, un yo complejo y variable conformado simultáneamente por una multitud de personalidades. Esta conjunción indecisa de yoes se manifiesta primero en la figura protagonista de Fragmentos de Apocalipsis, que confiesa sentirse unas veces Alberto Caeiro (heterónimo de Pessoa) y otras Abel Martín (heterónimo de Antonio Machado), aunque también afirma ser un espía internacionalmente buscado que ha decido refugiarse en una novela, y a veces dice ser un mero profesor universitario. De modo parecido se conforma también el yo autobiográfico de Dafne y ensueños, donde Torrente Ballester alterna su retrato real con el relato de sus fantasías infantiles para dar cuenta de los múltiples factores que lo determinaron como escritor. Aquí, la dependencia entre su yo autobiográfico y su yo imaginario es absoluta, pues ninguna de las dos partes alcanza autonomía para configurar una existencia sostenible.

El tercer camino, el de la multiplicidad total difusa, se explora con buenas dosis de ironía y parodia en Yo no soy yo, evidentemente. En esta obra, como se ha visto antes, el tema de la multiplicidad personal deja ya de ser un aspecto más de la novela para convertirse, desde el título mismo, en hilo que encauza la narración. Resumiremos aquí sucintamente el retorcido argumento de la novela: Mr. Sharp, un asentado lingüista estadounidense que siente brotar en sí una segunda personalidad poética, encarga a los profesores Ivonne y Álvaro que se desplazan a España para investigar la posible existencia de un tal Uxío Preto. Éste nombre correspondería a un desconocido escritor 
gallego que en su Autobiografía póstuma, además de contar algunos episodios autobiográficos, se atribuye la autoría de tres novelas publicadas anteriormente bajo los nombres de Néstor Pereyra, Pedro Teotonio Viqueira y Froilán Fiz respectivamente. Según reclama Uxío Preto, estos hombres no son escritores reales sino meros heterónimos adoptados por él a lo largo de su vida, a modo de personalidades desdobladas o pseudónimos literarios. En esta autobiografía, además, los investigadores estadounidenses hallan pistas de cómo encontrar a las personas retratadas, y a ellas se dirigen para desarrollar sus pesquisas y poder comprobar si en verdad Uxío Preto existió, si escribió las novelas que se atribuyó y si todavía seguía vivo. A partir de estas premisas, la novela se organiza en una estructura doble con capítulos intercalados de dos tipos: por un lado, los capítulos diarísticos sobre la investigación de Ivonne y Álvaro, donde entrevistan a diferentes testigos; y por otro, los tres capítulos intradiegéticos (Gamma, Zeta y Sigma) que componen la autobiografía póstuma de Preto, y que han sido incluidos para que los lectores puedan participar de la investigación con los mismos materiales que los protagonistas. Sin embargo, las pesquisas no resultarán sencillas en absoluto: movidos por oscuros intereses y rencores personales, algunos de los testigos confesarán no recordar nada, o no haber conocido a Preto sino a Pereyra o a Fiz en persona, desmentirán algunas anécdotas y añadirán más confusión a la trama. Al final, los investigadores deberán asumir que los sucesos narrados primero en las novelas de Uxío Preto, luego resumidos en su Autobiografía póstuma, y finalmente relatados por los testigos implicados constituyen tres versiones diferentes y sencillamente irreconciliables de lo acaecido; hasta el punto de que incluso la existencia de Uxío Preto queda puesta en entredicho. De este modo, la trama policiaca de la novela permanecerá finalmente irresoluta; el misterio de la identidad del escritor se pierde porque ninguna de las personas retratadas en las memorias de Preto consigue ofrecer una versión objetiva o al menos verosímil del pasado.

El hermetismo y sorprendente disposición deceptiva de esta novela, emblema de una época especialmente productiva en la prosa del gallego, ofrece multitud de interrogantes sin solución precisa. De hecho, como señala Emilie Guyard, la importancia del este libro dentro de la producción de Torrente Ballester no debe ser subestimada pues «en la medida en que Torrente deja de escribir novelas de fantasía después de 1987, podemos legítimamente considerar Yo no soy yo, evidentemente como el último, y por tanto estratégico, elemento de una larga práctica narrativa y reflexiva de la literatura de fantasía por parte del autor» ${ }^{10}$.

${ }^{10}$ Guyard, Emilie. «El enigma del Yo en Yo no soy yo, evidentemente», en Carmen Becerra y Emilie Guyard (eds.), Los juegos de la identidad movediza en la obra de Gonzalo Torrente Ballester, op. cit., pp. 113-123, 113. 


\section{LA INFLUENCIA DE PESSOA}

A la hora de adentrarse en el estudio de los aspectos centrales de la novela, es necesario subrayar ante todo cómo ésta gira entorno a la preocupación por la pluralidad personal. Este tono se corresponde bien con la tendencia general que Torrente Ballester mostró a lo largo de toda su carrera por ensayar diferentes formas de autorrepresentación dentro de sus ficciones. En Javier Mariño, en Don Juan, en Fragmentos de Apocalipsis o en Los años indecisos se puede observar su tendencia a crear personajes biográficamente cercanos, normalmente escritores o intelectuales relacionados con París o con una Galicia mítica; y de un modo parecido, Quizá nos lleve el viento al infinito, protagonizada por un espía, ofrece una encarnación simbólica del escritor, ya que tanto espías como escritores trabajan observando todo lo que sucede a su alrededor, interpretando eventos y adoptando otras personalidades como propias ${ }^{11}$. De hecho, este impulso de retratarse literariamente animó a un Torrente ya maduro a escribir incluso un relato sobre su infancia y primera juventud, Dafne y ensueños. Pero ni siquiera en este caso adaptó su prosa a los cánones del autobiografismo tradicional según fue descrito por Philippe Lejeune $^{12}$, es decir, la elaboración de un texto de apariencia fiable que permita establecer ante el lector un «pacto» de sinceridad. Torrente, por el contrario, lejos de construir un relato de apariencia objetiva para persuadir a sus lectores sobre la honestidad de sus confesiones biográficas, combinó de forma libre tanto la narración de sus recuerdos reales como de sus ensueños juveniles, colocando así lo acaecido y lo imaginado en planos equivalentes de existencia ${ }^{13}$. En cierto modo, se diría que el gallego sentía una cierta necesidad de retratarse en sus escritos, pero no podía concebir su autorrepresentación fuera de la ficción. Por supuesto, esta desconfianza de Torrente Ballester por el género biográfico tradicional es patente también en Yo no soy yo, evidentemente, pues la supuesta autobiografía póstuma de Preto no logra en absoluto dar una imagen fiel de cuál fue su verdadera historia, sólo una versión inevitablemente manipulada. Así, aunque esta novela no constituye en ningún punto una autobiografía, sí ofrece un ensayo inigualable sobre las posibilidades de una autorrepresentación verosímil según la poética torrentina.

${ }^{11}$ En la misma tradición del trasunto del espía como encarnación del escritor, el español Javier Marías ha publicado recientemente su notable novela Tu rostro mañana (2002-2007). Además, este autor madrileño también ha sido, al igual que Torrente, uno de los pioneros en introducir la novela «de campus» en España. Un género de intriga de ambientación universitaria que se perfila en Yo no soy yo y que Marías transita en su célebre Todas las almas (1989).

${ }^{12}$ Lejeune, Philippe (1975). Le pacte autobiographique. París: Seuil, p. 28.

${ }^{13}$ Para un análisis detallado sobre las obras autobiográficas de Torrente, véase el número dedicado al asunto por La Tabla Redonda, 4, 2006. 
A este respecto, cabe destacar que todos los personajes protagonistas de la novela (excepto los más negativos) se ven acosados por una inestabilidad crónica de su persona: Mr. Sharp asevera «a veces, me siento múltiple, me siento al menos doble, pero temo investigar más a fondo en mí mismo» ${ }^{14}$; Ivonne, mitad francesa e inglesa, y el mestizo don Álvaro conviven con su identidad dividida entre sus culturas de origen y su país de adopción; incluso la cuerda Ana María acabará al final de la novela poseída también por «una parte de ella misma, cuya existencia únicamente sospechaba» ${ }^{15}$; y, sobre todo, Uxío Preto, quien se esconde tras diversos heterónimos que, a su vez, se inventan sus propias personalidades en una cadena fractal. Dicha pluralidad se manifiesta no sólo en el contenido de la obra, sino, por supuesto, en su forma. De los ocho capítulos yuxtapuestos que conforman el libro, tres son epistolares (la carta de Preto que abre la novela, «El capítulo Zeta» que contiene la correspondencia entre Uxío y Pedro Teotonio Viqueira, y la nota de Álvaro que cierra el libro), otros tres conforman relatos narrativos (las dos intervenciones de Ivonne y «El capítulo Gamma» de la autobiografía de Preto), un capítulo recopila papeles de diario (de Ana María), y otro es una composición dramática en que intervienen múltiples voces («El capítulo Sigma»).

Para comprender por qué la noción de identidad de Torrente Ballester no estaba relacionada con el biografísmo o la omnisciencia sino con la polifonía, la novela fantástica y la reflexión metaliteraria, conviene tener en cuenta la gran afinidad que Torrente Ballester sintió siempre con el poeta portugués Fernando Pessoa. En infinidad de ocasiones, el novelista gallego afirmó y reiteró su pasión por los versos del escritor lusitano, con quien sentía una fuerte conexión personal y literaria ya que encontró en él un reflejo elaborado de las inquietudes creativas que siempre le obsesionaron. Como es bien sabido, Pessoa llevó a la cumbre de su excelencia la práctica de la heteronimia, es decir, la invención de autores ficticios, a veces con una biografía muy completa, que serían responsables de una creación literaria paralela a la del autor empírico o real ${ }^{16}$. Entre los cientos de heterónimos imaginados por Pessoa, tres de ellos (Alberto Caeiro, Ricardo Reis y Álvaro de Campos) configuraron incluso una cosmovisión y un estilo propio contrapuestos entre sí. Por tanto, no resulta extraño que algo de la pasión heterónima de Pessoa fuera finalmente heredada por Torrente Ballester, cuya prosa, aunque pasó por infinidad de fases y matices, siempre se caracterizó por jugar con el desdoblamiento personal.

${ }^{14}$ Torrente Ballester, Gonzalo (2008). Yo no soy yo, evidentemente. Madrid: Punto de Lectura, p. 49.

15 Ibidem, p. 473.

${ }^{16}$ Para más información véase la biografía de Crespo, Ángel (1988). La vida plural de Fernando Pessoa. Barcelona: Seix Barral, 1988; y el estudio de su poesía por Sadlier, Darlene J. (1998). An Introduction to Fernando Pessoa: Modernism and the Paradoxes of Authorship. Gainesville: University Press of Florida, 1998, pp. 9-26. 
Yo lo leí, por primera vez, hacia 1964, con evidente retraso. Mi información siempre fue mala, incluso para lo extraordinario. Comprendí repentinamente que entre aquel poeta y yo existían algunas afinidades de pensamiento y de sensibilidad, además de ser ambos géminis; o, dicho más modestamente, descubrí que Pessoa había pensado bastantes años antes lo que a mí me hubiera gustado pensar unos años después, si bien oscuramente lo sentía. ¿Se debe, esta afinidad, a la fecha de nacimiento, a esa coincidencia de fiestas del San Antonio de la Cabana y San Antonio de Lisboa, que son el mismo San Antonio? No lo sé. Dos géminis, sí; pero uno de ellos jamás vivió de inventarle horóscopos a la gente, ni dejó un baúl colmado de tesoros de poesía. Es también seguro que uno de ellos jamás dejó que en su interior creciera un Álvaro de Campos. ¿Para qué, si ya había crecido en otro seno imaginario ${ }^{17}$

Bajo álter egos, heterónimos, alusiones pseudoautobiográficas y narraciones metaliterarias, Torrente Ballester siguió siempre de cerca, aunque con sus propios matices, el camino de búsqueda de uno mismo a través de los demás que inaugurara en su día Pessoa. Para explicar su necesidad de asumir otras identidades, Pessoa comparaba la división de su persona en heterónimos con la despersonalización y simulación propia de la dramaturgia. Él, que se consideraba esencialmente un «poeta dramático», entendía la creación poética como una forma de sentir separadamente, es decir, de traspasar sus sentimientos a otra persona inexistente que, una vez conformada en su singularidad, podría percibir otras emociones que el poeta real nunca experimentó ${ }^{18}$. Así, la capacidad dramática de «otrarse» a la que aludía Pessoa no sólo puede relacionarse con el profundo interés de Torrente Ballester por el teatro, sino que sobre todo parece una reformulación poética de la separación que debe mediar entre autor y narrador en la prosa de ficción. Cuando Uxío Preto comienza a escribir su primera novela imbuido por la identidad de Néstor Pereyra alcanza una distancia objetivadora que le permite centrarse en su discurso y escribir fuera de sí mismo: "La voz interior que me dictaba no era, sin embargo, molesta; sabía insinuarse, y desde el primer momento advertí no sólo la nitidez de las imágenes sino la propiedad de las palabras que, sin la menor duda, me pertenecían ${ }^{19}$. Este distanciamiento personal replica en cierto modo el proceso bien establecido por la narratología francesa mediante el cual el autor debe conformar una voz independiente que encauce la ficción. Sólo con esta separación de instancias enunciativas llega a ser posible formar un mundo alejado de la referencialidad. «Le narrateur n'est pas l'auteur...; le narrateur est un personnage de fiction en qui l'auteur s'est métamorphosé», en palabras de Wolfgang Kayser ${ }^{20}$. En este sentido, el juego heterónimo de Pes-

${ }^{17}$ Torrente Ballester, Gonzalo. «Curriculum, en cierto modo». Op. cit., p. 121.

${ }^{18}$ Pessoa, Fernando. Odas de Ricardo Reis. Op. cit., p. 17.

${ }_{19}$ Torrente Ballester, Gonzalo (2008). Yo no soy yo, evidentemente. Madrid: Punto de Lectura, p. 175.

${ }^{20}$ Kayser, Wolfgang (1977). «Qui raconte le roman?», en Roland Barthes (ed.), Poétique $d u$ récit. París: Seuil, pp. 59-84, 72. 
soa, aun practicado sobre todo en el ámbito poético, parecería poder traducirse en el distanciamiento que todo autor de novelas debe establecer con su narrador.

Estos vericuetos de la voz narradora interesaron mucho a Torrente Ballester, quien, atraído siempre por el mundo luso y por las relaciones ibéricas, encontró en Pessoa un maestro cuya influencia, aunque llegara ya tardía en su vida, enriqueció el halo de autorreflexión inherente a toda su práctica literaria. Si ya en La sagalfuga de J.B. Bastida convive con sus heterónimos Basideira, Bastide, Bastid y Bastidoff, la influencia de Pessoa en la construcción de Yo no soy yo, evidentemente resultará aún más notable en todos los niveles. Mediante un paródico homenaje a las técnicas de desdoblamiento del poeta lusitano, Torrente Ballester da vida a un supuesto escritor gallego que inventa a su vez a tres escritores ficticios preocupados por la multiplicidad personal, el último de los cuales, el Sigma, Froilán Fiz, sufre además un problema de desdoblamiento de identidad que trata de exorcizar mediante la escritura de una novela sobre los problemas de identidad múltiple de dos hermanas gemelas. Aunque algunos testigos aseguran haber conocido a uno o a otros, finalmente la existencia extraliteraria de cualquiera de ellos no será demostrable. Más que en ningún otro texto de Torrente Ballester, aquí se pueden aplicar las palabras de David K. Herzberger sobre la evanescencia de los personajes del gallego: «There are no moments of epiphany for Torrente's characters, no soul-stirring affirmation of 'I am'. The characters are always becoming rather than being, hence all implications and potentials - the sum of which echoes life in the whole of its existenctial possibilities» ${ }^{21}$.

Estando Torrente Ballester fascinado por el juego de las identidades múltiples practicado por Pessoa pero siendo incapaz de aplicárselo a sí mismo con plena convicción - tal vez por el humorismo e ironía con que siempre observó la práctica literaria - se diría que buscó un álter ego ficticio que pudiera desarrollarse a través de tres heterónimos. Sin embargo, este juego heteronímico llevado a cabo aquí por Torrente Ballester presenta aspectos muy singulares. En Pessoa el lector queda como simple espectador de los deslumbrantes juegos de desdoblamiento y multiplicación de los yoes, pero la prosa narrativa de Torrente Ballester alberga e incluso requiere de la participación del lector. En Yo no soy yo, evidentemente, el lector juega un papel activo en la investigación de la figura de Uxío Preto: al igual que los protagonistas de la novela — críticos embarcados en una investigación sobre el autor de unos misteriosos textos-, también el lector debe tomar una decisión u optar por una posibilidad. Esta participación adquiere, de hecho, un sentido casi onto-

${ }^{21}$ Herzberger, David K. (1989). «Fragmentos de Apocalipsis and the Meaning of the Metafictional Character», en Janet Perez y Stephen Miller (eds.), Critical Studies on Gonzalo Torrente Ballester. Colorado: Society of Spanish and Spanish-American Studies, 1989, pp. 33-43, 41 . 
lógico puesto que los juegos metaliterarios de Torrente Ballester no se quedan meramente en la realidad ficcional. En un salto de niveles, las continuas identificaciones del autor empírico con sus personajes ficticios promueven un juego especular que viene a cuestionar los límites entre realidad y escritura.

Es decir, la sutil identificación de Torrente Ballester con Uxío Preto (ambos escritores y ambos gallegos) y la descripción de las relaciones de Preto con los heterónimos que inventa (Pereyra, Viqueira y Fiz) y de éstos con sus propios personajes creados, despliega un juego de muñecas rusas con escritores, personajes y lectores donde la situación del lector y del autor empíricos queda asimilada a la de los personajes de ficción ${ }^{22}$. Pero el hecho de que Torrente Ballester use los recursos de la metaficción para mostrar la inestabilidad con que conocemos nuestra vida, no implica que esté extrapolando las paradojas de la ficción al mundo real como hiciera Miguel de Unamuno en Niebla. Torrente Ballester no llega al extremo nominalista de negar que el mundo real pueda comprendido, sólo señala que las reglas que lo rigen nada tienen que ver con las de los mundos literarios, pues éstos gozan de autonomía total con respecto a la realidad. Es decir, que más allá de algunas relaciones básicas (la ficción por ejemplo sólo se puede construir a partir de experiencias en el mundo real), la esfera de la realidad y la de la ficción se rigen por leyes independientes. Así se manifiesta Uxío de conforme ante la aparición de un nuevo heterónimo:

Estas conclusiones, a las que llegué tras laboriosos análisis seguidos de enrevesadas deducciones, son las que me han permitido concluir la identidad esencial de cuatro figuras accidentalmente disímiles, aunque de la misma estatura. Que sea o no posible es algo que no me preocupó jamás, si se parte de la convicción inicial de que Pedro Teotonio Viqueira pertenece a la realidad por las vías inusuales de las concepciones imaginarias; cuya existencia, cuya biografía tienen que ser juzgadas de conformidad con una lógica algo apartada de eso que tenemos por normal; lo cual, por otra parte, jamás me causó grandes quebraderos de cabeza, dado que a la lógica al uso no suelo tenerla en cuenta, ni en mi conducta ni en mis imaginaciones: sencillamente, no me sirve ${ }^{23}$.

Así, en cierto modo, la única solución posible al misterio de la identidad de Preto y sus realizaciones heteronímicas consiste en no buscar ninguna coherencia entre su narración y lo que realmente pudiera acaecer, sino aceptar tal cual la coherencia intratextual. Es decir, lo relatado no tiene que responder ante ninguna realidad extratextual pues sólo a más textos, a más literatura. Por ello, a la hora de comprender la narración, lo importante no es la re-

${ }^{22}$ Vale la pena comparar la situación de Torrente con la de Pessoa a través de las siguientes palabras: «Afirmar que estos hombres, todos diferentes, todos bien definidos, que pasaron por su alma incorporadamente, no existen, no puede hacerlo el autor de estos libros; porque no sabe qué es existir, ni cuál, Hamlet o Shakespeare, es más real, o real de verdad» en Pessoa, Fernando. Odas a Ricardo Reis, op. cit., pp. 59-60.

${ }^{23}$ Torrente Ballester, Gonzalo. Yo no soy yo, evidentemente, op. cit., p. 292. 
solución del misterio de Preto ni sus consecuencias, sino seguir el desarrollo mismo del enigma y sus implicaciones internas.

\section{HACIA UNA AUTORREPRESENTACIÓN VEROSÍMIL}

En consonancia con el conocido debate sobre la capacidad mimética del lenguaje que durante los setenta y principios de los ochenta agitó el ámbito académico europeo y estadounidense, Torrente Ballester planteó en Yo no soy yo, evidentemente una interesante alternativa a las posibilidades de autorrepresentación ofrecidas hasta entonces por la autobiografía o la novela realista. Su peculiar experimento sobre los heterónimos y la impersonación literaria se enraíza, desde luego, con cuestiones teóricas aún hoy abiertas sobre la capacidad de la escritura para dar cabida y representar la realidad, ya sea un hecho histórico o la personalidad de un autor.

Autobiografía y memorias han conformado desde su nacimiento oficial en el siglo XVIII el canal más tradicional para el autorretrato literario. Pero estos géneros de no-ficción recibieron en los años setenta un ataque directo desde las teorías postestructuralistas y deconstructivistas, que llamaron la atención sobre el hecho de que esas formas de escritura son, en esencia, formalmente indistinguibles de la ficción. La crítica más feroz fue encabezada por Paul de Man, quien llegó a afirmar que toda reconstrucción lingüística de un hecho es inevitablemente una traición, pues el lenguaje no tiene capacidad para referirse directamente a la realidad sino que sólo alcanza a ser una metáfora de las cosas en $\mathbf{s i ́}^{24}$. Por supuesto, estas críticas tan polémicas no han evitado que la autobiografía se haya convertido hoy en día en un género en auge, y que los lectores sigan confiando en los pactos comunicativos mediante los que un autor muestra su honestidad hacia los hechos que narra. Sin embargo, las discusiones sí han servido para poner de relieve que la narración autobiográfica puede levantar sospechas sobre su veracidad, mientras que no tendría sentido poner en duda la verosimilitud de un relato de ficción durante su lectura.

Algo de esta lucha teórica se trasluce en Yo no soy yo, evidentemente, ya que el nudo principal de la intriga acabará siendo la notable falta de acuerdo entre los sucesos narrados en las novelas y en el retrato autobiográfico de Uxío Preto, los testimonios también incompatibles entre sí de los otros protagonistas, y la incapacidad de los profesores para discernir cualquier atisbo de verdad tanto a través de las páginas del libro como con su propia investigación de los hechos in situ. Los intentos frustrados de los protagonistas por acceder al verdadero rostro del escritor parecerían hacer hincapié en la incapacidad de la escritura para mostrar la realidad e incluso la limitación de nues-

\footnotetext{
${ }^{24}$ De Man, Paul (1979). «Autobiography as De-Facement», MLN, 94, 5, pp. 919-930, 930.
} 
tras propias aptitudes para conocerla. Pero la posición de Torrente Ballester va más allá de esta simple negación. Su denuncia no cae en la estéril idea de que toda concepción sobre el mundo o sobre uno mismo esté mediada por la ficción ni que sea una pura metáfora; al contrario, aunque las esferas de la realidad y la ficción no estén unidas en un sentido mimético tradicional, sí colaboran de forma necesaria porque la realidad sólo puede ser entendida de forma significativa a través de su narración, y porque la ficción no puede crearse sino a partir de una base de experiencias reales.

Los experimentos de Yo no soy yo van más bien dirigidos a buscar, con ayuda de las estrategias heterónimas heredadas de Pessoa, una forma auténtica aunque mediada por la ficción de plasmar la personalidad. Las figuras en que el portugués desdoblaba fragmentos de su personalidad no describían seres reales ni siempre coherentes, pero su existencia intratextual es innegable y poderosa. Del mismo modo, el interés de Torrente no anidaba en representarse de acuerdo a la verdad sino en explorar los límites de la verosimilitud. Por eso, desconfió de la autobiografía y las memorias, que ofrecen una autorrepresentación basada en un testimonio factual y en un compromiso de sinceridad, para centrarse en cómo dibujar la identidad a través de la ficción, cuya capacidad de convicción radica sólo con el poder persuasivo de las palabras. Cabe decir que la fuerte inclinación de Torrente hacia el irrealismo y la fantasía, obligó también a que su noción de la representación personal se alejara del compromiso de veracidad propio de los escritos realistas para apoyarse sólo en la verosimilitud del lenguaje narrativo. Así habla Torrente sobre la revelación que para él supuso la redacción de Fragmentos de Apocalipsis, obra creada a través de la misma técnica irrealista que Yo no soy yo, y fundamental en el recorrido de su segunda etapa creativa:

\begin{abstract}
Durante su concepción y redacción se repitieron circunstancias ya descritas. Son nuevas visiones de mis temas de siempre: el amor, el poder, el mito, con alguna novedad, como mi fe en el poder de la palabra como fundamento, como sustentación de realidades imaginarias, fuesen o no fantásticas; de donde deduje la inutilidad del «realismo», puesto que, cualquiera que sea la dependencia de lo narrado con la realidad (la imaginación sólo opera sobre experiencias vivas) y su mayor o menor proximidad, lo narrado o descrito sólo subsiste por la palabra, y, cualquiera que sea su naturaleza, pertenece a la realidad de lo poético ${ }^{25}$.
\end{abstract}

El logro de la narración literaria, por lo tanto, consiste en ofrecer una reconstrucción más significativa de lo real y de la personalidad gracias a la disposición significativa de los sucesos. Así, Yo no soy yo, evidentemente puede entenderse como una forma de mostrar que la narración constituye un canal válido para encauzar un autoconcepto: el Uxío Preto pretendidamente histórico se diluye mientras que sus fragmentarias versiones narrativas perma-

${ }^{25}$ Torrente Ballester, Gonzalo. «Nota autobiográfica», op. cit., p. 21. 
necen. Lejos del tópico de lo narrativo como antítesis de la verdad, como imagen engañosa o deformada del mundo, aquí se impone como parte necesaria de la memoria. Esta noción torrentina del estatuto epistemológico de los textos narrativos de ficción se emparenta con las consideraciones filosóficas del giro lingüístico, ampliamente extendidas desde mediados del siglo $\mathrm{XX}$, sobre todo en su concreción en la Teoría de la Acción Comunicativa de Habermas $^{26}$.

Como es sabido, dicha corriente se centra en las dificultades de acceder a la realidad como objeto de conocimiento y en la función constitutiva del lenguaje. Según sus postulados, el conocimiento de un referente viene siempre mediado por el significado desde el que el sujeto lo comprenderá. En este sentido, el lenguaje debe ser definido como un medio de entendimiento, y nunca como una puerta de acceso a la percepción plana de lo real. Así pues, ¿qué papel puede asumir el sujeto tras haber desaparecido como elemento estable en el proceso de conocimiento? Esta teoría apuesta por destacar el uso comunicativo, y no meramente instrumental, que los individuos hacen del lenguaje. La teoría habermasiana propugna que el lenguaje tiene una función de comunicación intersubjetiva que permite concretar tradiciones de interpretación entre los hablantes, y por tanto, garantiza la objetividad. En cuanto al lenguaje literario, se insiste en anulación referencial de la literatura con el mundo empírico y su estatuto autónomo. Los lectores podrán interpretar por tanto dichos mundos según diversos significados, admitiéndose así la ambigüedad como un hecho inherente al acto literario. En este sentido, ninguna de las frases que componen un texto de ficción literaria puede ser considerada «verdadera» o siquiera «mimética». La ficción es un universo intrarreferencial, sustentado sólo en sus palabras, que no puede ser juzgado mediante ningún rasero exterior. Es decir, las ficciones narrativas configuran una categoría ontológica propia sin relación con los criterios de verdad o falsedad propios del mundo real. Por tanto, como concluye el propio Torrente, la literatura no necesita ser «realista» para ser «creíble» pues «esta capacidad de convicción no se obtiene copiando o imitando lo real, sino poniendo en juego medios estrictamente literarios que cobran su sentido en el contexto total de la novela y del personaje» ${ }^{27}$.

Según estas ideas, analizar la ficción como recreación imitativa del mundo externo significa caer en una crítica ingenua que confunde lo verosímil con lo verdadero. La narrativa ficticia en general, incluso la de apariencia más «realista», no puede ser juzgada por raseros convencionales de adecuación a la verdad sino que debe ser concebida como un universo propio, cerrado so-

\footnotetext{
${ }^{26}$ Bobes, $\mathrm{M}^{\mathrm{a}}$ del Carmen (2008). Crítica del pensamiento literario. Madrid: Arco/Libros, pp. $281 \mathrm{y} \mathrm{ss}$.

${ }^{27}$ Torrente Ballester, Gonzalo (1975). El 'Quijote' como juego. Madrid: Guadarrama, p. 117.
} 
bre la única razón de su misma coherencia interna, que establece relaciones sociales de naturaleza completamente independiente con sus usuarios. Los únicos hechos que componen un mundo de ficción son las frases emitidas por el narrador en el propio acto de enunciación. En otras palabras, un lector puede aprender y discurrir sobre el mundo real gracias a la lectura de novelas, aprender datos y recibir incluso lecciones morales; pero más allá de los usos que se hagan de la ficción, si hablamos sólo de la sustancia textual que compone un mundo de ficción, es necesario convenir que su coherencia y valores de verdad son puramente internos.

Tal y como expone Lubomir Dole $e^{28}$, a la hora de analizar un texto de ficción no se pueden asignar valores de verdad a las afirmaciones del narrador porque no se refieren a un mundo, sino que más bien construyen un mundo. Los enunciados del narrador son los ladrillos que erigen un mundo imaginario ante los ojos del lector, de modo que no cabe dudar de ellos, pues por su mera presencia son inequívocamente «auténticos». La falta de coherencia interna del propio texto es el único referente en torno al cual se puede debatir la verosimilitud o no de un relato. En este sentido, la noción de mímesis ha sido sustituida por el concepto de «necesidad», también de origen aristotélico. Es decir, la verosimilitud de un texto no radica en reflejar un aspecto de la realidad, sino en su disposición u ordenamiento lógico en términos de causa y efecto. Como Carmen Becerra comenta al respecto de la «impresión de realidad» en la prosa de Torrente Ballester «esa impresión se obtiene no por mímesis, sino por una cuidadosa selección y ordenación verbal, de donde se concluye que la verosimilitud de lo narrado no es un problema de inventio, sino de dispositio» ${ }^{29}$. De un modo parecido lo declara el propio Torrente:

De las tres etapas en que los antiguos retores (¡ojo, linotipista: sin c!) dividían la invención del discurso, ni la invención ni la elocución me causan grandes quebraderos: lo que consume mi tiempo y mi ingenio, lo que me sume en dudas, lo que me lleva al acierto o desacierto, es la composición, y no por falta de ocurrencias, sino quizá, por exceso, o por lo difícil que resulta (algunos, pocos, lo saben) averiguar la forma que cada material exige desde dentro de sí misma como una exigencia de vida. No se olvide que ese código que, según la terminología moderna, incluyen nuestros genes, no sólo contiene las órdenes de vida, sino la forma ${ }^{30}$.

Gracias a esta independencia de la ficción con respecto a las leyes que rigen el mundo real, durante su segunda etapa creativa Torrente Ballester

\footnotetext{
${ }^{28}$ Dole•el, Lubomir (1998). Heterocosmica, Fiction and Possible Worlds. Londres: Johns Hopskins University Press, pp. 13-48.

${ }^{29}$ Becerra, Carmen. «Los espejos del yo», en Carmen Becerra y Emilie Guyard (eds.), Los juegos de la identidad movediza en la obra de Gonzalo Torrente Ballester, op. cit., pp. 67-82, 68.

${ }^{30}$ Torrente Ballester, Gonzalo. «Nota autobiográfica», op. cit., p. 21.
} 
apostó por una narrativa alejada del realismo y comprometida con la innovación formal. Estructuralmente, su narrativa siguió derroteros experimentales cercanos a la metaficción, con habituales digresiones expositivas típicas del ensayo; temáticamente, recreó historias cercanas al mito, la fantasía y lo maravilloso pero ambientadas en escenarios costumbristas. Sin embargo su espíritu innovador no sólo le llevó a superar la dependencia de la literatura con respecto a la imitación de la realidad, sino que también le impulsó a buscar los límites de la verosimilitud y a forzar la coherencia interna de sus textos. Si la necesidad aristotélica se entiende como una ordenación causal que debe darse de forma estricta, de modo que si se suprimiese o agregase algún evento se dislocaría totalmente el conjunto de la obra, Torrente Ballester ensayó diversas formas de superar esta disposición causa-efecto. En las obras de su segundo periodo, pero sobre todo en Yo no soy yo, se puede observar ese impulso de poner a prueba la capacidad persuasiva de la ficción. ¿Hasta qué punto es posible mantener la «suspensión de la incredulidad» en la lectura de un texto de estructura azarosa, que no parece responder a una disposición causal y cuyo narrador ironiza continuamente sobre sus capacidades para elaborar un relato creíble? Para responder a la pregunta, Yo no soy yo explora los límites de la verosimilitud a través de dos recursos: una voz narradora de dudosa fiabilidad que no alcanza a proveer de autenticidad narrativa su relato por un lado, y la falta de una disposición teleológica de los eventos por otro.

Respecto al primer recurso se debe tener en cuenta que los hechos del discurso ficticio son establecidos por la voz del narrador, única figura con autoridad suficiente. Pero este poder del narrador para crear nuevas realidades ficticias con cada uno de sus enunciados no es absoluto sino más bien gradual: los narradores objetivos (como los que se expresan a través de la omnisciencia y la tercera persona) crearán mundos coherentes, pero la subjetividad (los narradores en primera persona o aquellos con conocimientos deficientes de la trama) conllevará mundos menos estables y de creciente dificultad de acceso para el lector. Es decir, los mundos narrativos están determinados por la forma de su expresión (forma como contenido) porque la autoridad del narrador se ve afectada si manifiesta actitudes como dudas, creencias o presuposiciones. De hecho, la autoridad del narrador en primera persona será ya sólo relativa, pues al adquirir esta figura una personalidad concreta, los hechos que construyen sus frases pueden estar fusionados con comentarios acerca de creencias subjetivas. Además, en casos extremos, el narrador puede llegar incluso a poner en duda explícitamente su propia autoridad narrativa, de modo que el narrador introduce motivos narrativos y construye hechos de su universo ficticio pero se muestra tan inconsistente que siembra dudas sobre su autenticidad ante el lector.

Los dos mecanismos que cita Dole $e^{31}$ a través de los cuales el narrador

${ }^{31}$ Dole•el, Lubomir (1980). «Truth and Authenticity in Narrative», Poetics Today, I, 3, pp. 7-25, 20-25. 
puede poner en peligro la coherencia interna, y por lo tanto la verosimilitud, de un texto son la ironía y el discurso metaficcional. Mediante estos mecanismos, es capaz de enunciar hechos de su mundo ficcional al mismo tiempo que levanta también sospechas sobre sus propias afirmaciones. Yo no soy yo reúne un amplio grupo de narradores que, a pesar de expresarse siempre desde la primera persona, ofrecen al lector un abanico de puntos de vista. Los capítulos narrados por Ivonne, Álvaro y Ana María ofrecen una perspectiva subjetiva pero con un discurso coherente y cuyos razonamientos se rigen por el orden causa-efecto. Sin embargo, los episodios de la autobiografía de Uxío Preto muestran a un narrador inestable, paródico, contradictorio, que se pone en duda a sí mismo y cuyo discurso se vuelve cada vez más metarreferencial. Desde la primera aparición de Uxío en su epístola pública hasta el último capítulo de su autobiografía, el discurso de este autor supuesto se irá haciendo más confuso a cada intervención. Así, el capítulo Sigma se ambienta en un vago escenario teatral apenas corpóreo («Ámbito global de luz difusa embutido en un círculo de sombras: lugar sin existencia física, no por eso menos real» ${ }^{32}$ ), donde dos personajes apenas dibujados reconstruyen una historia irresoluta (nada se sabrá finalmente sobre los destinos de Froilán y Melitón) mientras dudan continuamente de su existencia ( Nada de lo que te rodea es real, y es probable que yo tampoco lo sea» ${ }^{33}$ ). La conciencia metaliteraria de los personajes y la abundancia de reflexiones sobre lo artificial de su situación ponen de manifiesto lo inestable de la narración. Este mundo creado pero no autentificado por Preto se podría considerar ambiguo, problemático o indefinido pues ocuparían un espacio intermedio entre la existencia y la no existencia ficcional.

Respecto a la disposición de sus elementos, Yo no soy yo destaca por su estructura en forma de novela policíaca deceptiva. A lo largo de la obra se van acumulando diferentes ingredientes de novela de misterio, de modo que se crea la expectativa de un avance encadenado que conducirá necesariamente a una resolución del dilema. Sin embargo, el final no llevará a ningún tipo de desenlace, sino que el misterio de la identidad de Preto seguirá tan intacto como al principio: «Estamos como estábamos al empezar, y no se vislumbra un más allá» ${ }^{34}$ es la única conclusión que Álvaro puede ofrecer a su socia Ivonne. La novela, alineándose en la categoría de relatos que Patricia Waugh llama «metafictional thriller» ${ }^{35}$, ofrece una reflexión en torno a cuestiones filosóficas y literarias, pero renuncia a la disposición teleológica de sus elementos. Ante la falta de conclusión, las diferentes partes del relato, que antes

\footnotetext{
${ }^{32}$ Torrente Ballester, Gonzalo. Yo no soy yo, evidentemente, op. cit., p. 425

${ }^{33}$ Ibidem, p. 468.

${ }^{34}$ Torrente Ballester, Gonzalo. Yo no soy yo, evidentemente, op. cit., p. 498.

${ }^{35}$ Waugh, Patricia (1984). Metafiction: the theory and practice of selfconscious fiction. Londres: Routledge, p. 84.
} 
prometían algún tipo de coherencia, quedan dispersas, convertidas en incógnitas. Esta falta de resolución final, aunque contraria a las expectativas del lector y a la resolución de las líneas de necesidad que deberían haber guiado la trama del relato, es de hecho una reivindicación irrealista de falsedad que implica dotar de significado a los eventos dispersos que conforman la vida, e incluso de la posibilidad de acceder a cualquier verdad estable. Mr. Sharp, en su calidad de lingüista, no halla un método científico para categorizar la literatura de Uxío Preto; tampoco Ivonne, especialista en Historia de la Literatura, logra que la reconstrucción testimonial de la vida del supuesto escritor dé algún fruto concreto; y ni siquiera Álvaro, con su moderno acercamiento a la crítica artística y filosófica, puede obtener un mejor resultado. A este respecto, la novela anuncia el estilo que años después se convertirá en eje de $L a$ muerte del Decano (1992), donde Torrente recurre a los tópicos del género policiaco - también en su variante de intriga de campus-, para desmotar de nuevo la visión ingenua y positivista de los procesos investigadores que pretenden encontrar la verdad a través de la ciencia, la historia, la literatura o la filosofía ${ }^{36}$.

\section{CONCLUSIONES}

El esfuerzo de creación en Yo no soy yo, evidentemente de un mundo antirrealista pero aun así verosímil para el lector, resume las ideas sobre la ficción que Torrente ensayó durante toda su carrera. Como muestra la evolución de su trayectoria en sus dos primeras etapas creativas, Torrente fue asumiendo una perspectiva peculiar ante la cuestión de la naturaleza de la ficción, y llegó a concebir el orden literario como un ámbito semánticamente apartado del mundo real. Por ello, en el centenario del nacimiento del gallego, Yo no soy yo reclama una mayor atención por parte de la crítica, pues posee un significado literario de especial relevancia como última manifestación de una de las etapas creativas más productivas y personales del gallego, y alberga además una verdadera «arte poética» en su interior. Entre burlas y veras, Torrente construye en esta obra un tratado teórico-práctico en torno a los presupuestos estéticos que siempre guiaron su trayectoria. En concreto, los contenidos metaliterarios que encierra el texto resumen bien las inquietudes de Torrente sobre la ontología de la ficción narrativa, especialmente en cuanto a cómo representar la experiencia personal de un autor de forma verosímil.

Como se ha revisado aquí, en la postura de Torrente las interpretaciones sociales y semánticas conviven de forma armónica y productiva. Por supuesto, toda novela puede ofrecer conocimientos y saberes aplicables a la vida,

\footnotetext{
${ }^{36}$ Colmeiro, José F. (2004). «Historia y metaficción en 'La muerte de un Decano' de Torrente Ballester», La Tabla Redonda, 2, pp. 135-150, 147.
} 
sobre todo porque la ficción se inspira en la experiencia; pero por lo que respecta al funcionamiento interno de las ficciones literarias, sus universos se sustentan en normas propias donde no prima la verdad o la referencia sino sólo la verosimilitud. La poética torrentina muestra así la influencia de las corrientes filosóficas del giro lingüístico que tan determinantes fueron para la teoría artística del siglo XX. En concreto, sus planteamientos se relacionan bien con la Teoría de la Acción Comunicativa habermasiana, pues tal y como Torrente fue exponiendo en sus novelas, los mundos imaginarios no necesitan construirse subordinados a la mímemis, sino a la diégesis o coherencia interna. Es decir, su verosimilitud no se basa en la imitación fidedigna de la realidad extraliteraria sino en la autonomía de las palabras para construir mundos significativos. Gracias al poder persuasivo del lenguaje, cualquier mundo imaginario, aún el más rocambolesco y metaparódico, puede ser creíble para el lector, pues el sentido intraliterario es autónomo y se basta a sí mismo como justificación. Por eso, para Torrente Ballester, escribir un relato personal o autobiográfico sobre un ser real responde al mismo orden de creación que la escritura sobre un personaje inventado o un heterónimo: el de las meras palabras. Así, la práctica literaria permite unir la recreación de otros mundos con la recreación personal, de modo que el proceso de escritura se convierte en campo idóneo para la investigación de la multiplicidad personal. Según el mismo Torrente afirmaba, escribir supondría una forma de actualización de todos los seres posibles que habitan en la conciencia del creador, por lo menos para los escritores imaginativos que «proyectan personalidades distintas y tienen la capacidad de vivirlas, hablando siempre en metáfora» ${ }^{37}$. Este juego con la otredad que Torrente Ballester practicó por influencia de Fernando Pessoa sólo vino a actualizar la predisposición natural del gallego a desdoblarse en álter egos. Por eso, pudo apropiarse de esta influencia desde el tono humorístico y desenfadado que siempre caracterizó su labor creativa. Por ejemplo, la constate ironía del estilo de Torrente le impidió asumir con seriedad el juego de los heterónimos para sí mismo, y sólo lo reservó para los narradores de sus novelas como Froilan Fiz y compañía. Además, a diferencia de Pessoa, Torrente se empeñó en que el juego de la otredad también alcanzara al lector por distintas vías, gracias a la proyección de nivolescas identificaciones entre autor/personaje al plano de la realidad del lector empírico, y gracias también a la propuesta de un juego de investigación policiaca finalmente truncada.

En este sentido, la excepcional originalidad de Torrente Ballester y su relevante puesto en la historia de la literatura española contemporánea no pueden explicarse sin tomar en cuenta las investigaciones de creación de mundos y autorrepresentación que Torrente llevó a cabo durante la segunda

\footnotetext{
${ }^{37}$ Goñi, Javier (1984). «Gonzalo Torrente Ballester, un hombre tranquilo», Ínsula, 452453, p. 11.
} 
etapa de su carrera. Su acuciante búsqueda de una teoría literaria que pudiera dar cuenta de los sorprendentes mecanismos de la ficción y la verosimilitud culminó con una sorprendente pirueta en Yo no soy yo. El texto supuso para el gallego la prueba definitiva de que la credibilidad de las palabras podía sustentar cualquier ficción. Por ello, del mismo modo que había abandonado antes los caminos del realismo, acabó por renunciar a los del irracionalismo para buscar un punto de equilibrio entre las dos tendencias que siempre dominaron su escritura. En conclusión, el análisis de la compleja teoría narrativa que imbuye Yo no soy yo resulta un elemento indispensable para acercarse con éxito a la amplia producción de este excepcional escritor.

\section{BIBLOGRAFÍA CITADA}

Becerra, Carmen (2008). «Los espejos del yo», en Carmen Becerra y Emilie Guyard (eds.), Los juegos de la identidad movediza en la obra de Gonzalo Torrente Ballester. Vigo: Academia del Hispanismo, pp. 67-82.

Bobes, $\mathrm{M}^{\mathrm{a}}$ del Carmen (2008). Crítica del pensamiento literario. Madrid: Arco/Libros, 2008.

Colmeiro, José F. (2004). «Historia y metaficción en 'La muerte de un Decano' de Torrente Ballester», La Tabla Redonda, 2, pp. 135-150.

Crespo, Ángel (1988). La vida plural de Fernando Pessoa. Barcelona: Seix Barral.

De Man, Paul (1979). «Autobiography as De-Facement», MLN, 1979, 94, 5, pp. 919-930.

Dole•el, Lubomir (1980). «Truth and Authenticity in Narrative», Poetics Today, I, 3, pp. 7-25.

Dole•el, Lubomir (1998). Heterocosmica, Fiction and Possible Worlds. Londres: Johns Hopskins University Press.

Gil González, Antonio J. (2003). Relatos de poética: para una poética del relato de Gonzalo Torrente Ballester. Santiago de Compostela: Universidad de Santiago de Compostela, pp. 39-110.

Gil González, Antonio J. (2008). «Identidad y mutación en la 'novelística del yo' de Gonzalo Torrente Ballester: Quizá nos lleve el viento al infinito y otras narraciones indecisas», en Carmen Becerra y Emilie Guyard (eds.), Los juegos de la identidad movediza en la obra de Gonzalo Torrente Ballester. Vigo: Academia del Hispanismo, pp. 83-103.

Goñi, Javier. (1984). «Gonzalo Torrente Ballester, un hombre tranquilo», Ínsula, pp. 452-453.

Guyard, Emilie (2008). «El enigma del Yo en Yo no soy yo, evidentemente», en Carmen Becerra y Emilie Guyard (eds.). Los juegos de la identidad movediza en la obra de Gonzalo Torrente Ballester. Vigo: Academia del Hispanismo, pp. 113-123.

Herzberger, David K. (1989). «Fragmentos del Apocalipsis and the Meaning of the Metafictional Character», en Janet Perez y Stephen Miller (eds.), Critical Studies on Gonzalo Torrente Ballester. Colorado: Society of Spanish and Spanish-American Studies, pp. 33-43.

Kayser, Wolfgang (1977). «Qui raconte le roman?», en Roland Barthes (ed.), Poétique du récit. París: Seuil, pp. 59-84.

Lejeune, Philippe (1975). Le pacte autobiographique. París: Seuil, 1975.

Loureiro, Ángel G. (1990). Mentira y seducción: la trilogía fantástica de Torrente Ballester. Madrid: Castalia.

Mendoza, Ana (2009). «Homenaje a Gonzalo Torrente Ballester por la reedición de Los gozos y las sombras». [En línea]. elmundo.es. 14 noviembre 2007, http://www.elmundo.es/ elmundo/2007/11/14/cultura/1195042569.html [consulta: 10 septiembre 2009]. 
Pessoa, Fernando (1980). Odas de Ricardo Reis, Gonzalo Torrente Ballester (pról.). Valladolid: Balneario Ediciones.

Pozuelo Yvancos, José María (2004). Ventanas de la ficción. Barcelona: Península.

Sadlier, Darlene J. (1998). An Introduction to Fernando Pessoa: Modernism and the Paradoxes of Authorship. Gainesville: University Press of Florida, pp. 9-26.

Saramago, José (1997). «Perfiles cervantinos en la obra de Torrente», en Carmen Becerra, Ángel Candelas y Ángel Abuín González (eds.), La creación literaria de Gonzalo Torrente Ballester. Vigo: Tambre, pp. 13-22.

Torrente Ballester, Gonzalo (1975). El 'Quijote' como juego. Madrid: Guadarrama.

Torrente Ballester, Gonzalo (1986). «Nota autobiográfica», Anthropos, 66-67, pp. 19-21.

Torrente Ballester, Gonzalo (2006). «Curriculum, en cierto modo», La Tabla Redonda, 4, pp. 121-136.

Torrente Ballester, Gonzalo (2008). Yo no soy yo, evidentemente. Madrid: Punto de Lectura, 2008, p. 49.

Waugh, Patricia 1984). Metafiction: the theory and practice of selfconscious fiction. Londres: Routledge.

Fecha de recepción: 1 de diciembre de 2009

Fecha de aceptación: 16 de julio de 2010 